\title{
Drivers of tree presence and densities: the case of cocoa agroforestry systems in the Soubre region of Republic of Côte d'Ivoire
}

\author{
Amos Gyau • Kaitlyn Smoot • Lucien Diby • \\ Christophe Kouame
}

Received: 6 September 2013/Accepted: 29 September 2014/Published online: 7 October 2014

(C) The Author(s) 2014. This article is published with open access at Springerlink.com

\begin{abstract}
Cocoa yields in Côte d'Ivoire are low and falling each year, in part as a result of full-sun cropping systems. Thus, interest is now high in establishing sustainable cocoa agroforests through the re-introduction of shade trees. This article uses data collected from a sample of 400 cocoa farmers in the Soubré region of Côte d'Ivoire to rank the top alternative tree species of interest to farmers and to analyze the determinants of their presence and density in cocoa farms. Results show that the most significant determinants are: social network effects, ethnic group, and geographic zone. Also, poorer farmers and those in more isolated villages were more likely to associate their cocoa with crops popular for household consumption like oil palm. We thus suggest that future agroforestry programs should tailor the tree species promoted based on location, ethnic group, market access, and income level, and that extension programs
\end{abstract}

\footnotetext{
A. Gyau ( $\square)$

World Agroforestry Centre, United Nations Avenue,

Gigiri, P. O. Box 30677, Nairobi 01000, Kenya

e-mail: a.gyau@cgiar.org
}

K. Smoot

Department of Agricultural and Resource Economics, University of California, Davis, One Shields Avenue, Davis, CA 95616, USA

\section{Diby · C. Kouame}

World Agroforestry Centre, Cocody Mermoz, Avenue 9, 08 BP 2823, Abidjan 08, Ivory Coast should be designed to take advantage of networking effects.

Keywords Côte d'Ivoire $\cdot$ Agroforestry $\cdot$ Shade tree $\cdot$ Cocoa $\cdot$ Diversification

\section{Introduction}

The issue of promoting sustainable agricultural production systems is increasingly receiving attention from Governments, development practitioners, researchers and consumers in many parts of the world. This is against the background of environmental degradation, deforestation, climate change and food security which threatens the livelihoods of many people especially in developing parts of the world. This notwithstanding, agricultural practices in many developing countries still adhere to unsustainable practices such as intensive farming systems which may result in short term increase in productivity but may experience considerable decline in the long term. This trend seems to be happening in the cocoa industry in Côte d'Ivoire where yields per land area is among the lowest in the world, averaging 200-500 kg/ha and has been decreasing over time (Assiri et al. 2012, Fair Labor Association (FLA) 2012) which is far below onstation yields which averages $2,000 \mathrm{~kg}$ per ha. Furthermore, cocoa production in Côte d'Ivoire decreased by $16 \%$ from $1,380 \mathrm{mt}$ in $2007 / 2008$ to 
1,160 mt in 2008/09 (International Institute of Tropical Agriculture (IITA) 2009). One reason for this is the fact that the dominant full-sun, mono-cropped cocoa systems in Côte d'Ivoire which increase yields in the short-term lead to severe long-term depletion of soil nutrients. Cocoa grown in this way requires rotation to new land after a period of 20-30 years and as a result caused deforestation (Ruf 2001).

However, the disappearance of virgin forest in Côte d'Ivoire means that this type of farming is no longer sustainable (Ruf 2001; Asare 2005) necessitating a new model for cocoa farming. Recent research has shown that cocoa systems which incorporate other tree species for shade, moisture retention, and fertility are more sustainable in the long-term and only experience a small decrease in yields under ideal conditions (Asare 2005; Ofori-Frimpong et al. 2007; Cloug et al. 2009). Cocoa grown in Nigeria, most regions of Ghana (excluding the Western region), and particularly Cameroon is grown under much higher shade levels and have not experienced the same long-term yield declines as the full-sun systems in Côte d'Ivoire (Gockowski and Dury 1999). In addition, it has been observed that under certain soil conditions and rainfall regimes shaded cocoa may yield for 60-100 years whereas production may last for only 20 years without shade (Obiri et al. 2007). Studies comparing shaded and un-shaded cocoa have revealed that shaded systems speed the breakdown of leaf litter and result in higher natural nitrogen and phosphorous levels in the soil indicating that shaded cocoa production system is more sustainable compared to unshaded Ofori-Frimpong et al. (2007).

Furthermore, well-designed agroforestry systems can also help to decrease the spread of diseases, particularly Cocoa swollen shoot virus (CSSV), if appropriate species are used as barriers around cocoa fields. On the other hand, some other trees are hosts for CSSV and these species must be avoided in the promotion of cocoa agroforestry (Akrofi et al. 2003; Asare 2005).

Another element of sustainability is economic diversification. Currently majority of cocoa farmers in Côte d'Ivoire depend solely on cocoa farming revenues, meaning that crop failure, increased input prices, or adverse purchasing conditions can be disastrous for them. If farmers had a more diversified income base then they would face less risk from price fluctuations and crop failure, and would have higher overall incomes (Gibson 2007). Somarriba and Beer (2011) argue that timber from cocoa shade canopies helps satisfy the construction needs of the household since timber can serve as saving account and a safety net for households, helps to generate additional income which is crucial in times of low cocoa prices or diseases infestation, and helps to increase the value of the land. Part of the increased income could be used to make higher investments in cocoa to ensure higher and more reliable production.

Tree species found in cocoa farming system in Côte d'Ivoire can be categorized in two groups. The first is the group of spontaneous or native species which are naturally regenerated and are therefore randomly distributed across the cocoa landscapes. These species are set apart by farmers for shade management mainly during the dry season, soil fertility management, soil erosion etc. (Dumont et al 2014). The most important in terms of distribution of these species are Entandrophragma angolense, Milicia excelsa, Nesogordonia papaverifera, Terminalia ivorensis, Triplochiton scleroxylon, Alstonia boonei, Anthocleista nobilis, Antiaris toxicaria, Ceiba pentandra, Petersianthus macrocarpa, Pycnanthus angolense, and Sterculia tragacantha (Dumont et al 2014). The second group includes tree species that are planted or raised together with cocoa in a crop diversification system. These species are valued for different purposes such as nutrition, income, medicine, firewood and timber (Adou Yao and N'Guessan 2006). The main species of this group include Elaeis guineensis, Cocos nucifera, Cola nitida, Musa paradisiaca, Spondias mombin, Psidium guajava, Mangifera indica, Bombax buonopozense, Dacryodes klaineana, Garcinia kola, Persea americana, Citrus sinensis, Citrus limon and Irvingia gabonensis, Ricinodendron heudelotii. Elaeis guineensis and Cola nitida. These trees although are natives to Ivorian humid forest, but unlike other native species, they are also planted by farmers given their importance (Aké-Assi 2001; 2002). In addition to these species, some exotic species (Acacia auriculiformis, Acacia mangium, Albizia guachapele, Albizia lebbeck, Gliricidia sepium) have been evaluated and proposed by researchers and extension personnel to farmers. These are legume species with Gliricidia sepium as the most widely promoted species. Although, farmers recognized the contribution of Gliricidia sepium for soil fertility improvement, shade management and weed control (Kouadio et al. 2011), 
this species has not been adopted in many places because its management requires regular pruning to avoid competition with cocoa plants (Kouadio et al. 2011).

Cocoa certification bodies like Rainforest Alliance and UTZ include environmental standards which includes shade trees on cocoa farms. This has led to increase in the promotion of shade trees and agroforestry practices in Côte d'Ivoire in recent years (Tropical Commodity Coalition (TCC) 2010; Matissek et al. 2012). The Ivoirian extension service (ANADER) has also begun promoting cocoa agroforestry, often in partnership with certification bodies. In order to design the best interventions to promote tree planting among cocoa farmers, it is important to understand what tree species are currently of interest to farmers in the area and why. To that end, this article aims to identify the tree species which are of interest to farmers and examines the determinants of the presence and density of these species. This information will be useful in tailor-made promotional strategy for agroforestry practices among cocoa farmers in Cote d'Ivoire. The key lessons learned could also be applied in other parts of the world where agroforestry practices and sustainable production systems are of interest.

\section{Materials and methods}

Study area

The area covered in this study was the department of Soubré (land area $8,306 \mathrm{~km}^{2}$ ), located in the southwest of Côte d'Ivoire. This area was selected because it is an important cocoa producing area, contributing about $20 \%$ of national cocoa production (ICRAF 2011). The total population of the department of Soubré in 2012 was approximately 942,362 people (ICRAF 2011) with a population density of 76 people per $\mathrm{m}^{2}$. This is much higher than the national average due to the attraction of the cocoa economy, which has led to a great deal of migration into the area from other parts of Côte d'Ivoire and from other countries.

Kouadjo et al. (2002) found that among the agricultural population, cocoa was found to account for $66.8 \%$ of income on average, while coffee, food crops, rubber, livestock and palm were other important sources of income. In 2010 there were 173,609 ha under cocoa production in Soubré, an average of about 6.4 ha per household (Smoot et al. 2013). Soubré has a typical equatorial climate, with two rainy seasons and two dry seasons per year. The average annual rainfall across the 1999-2008 period was 1,362.8 $\mathrm{mm}$. There are essentially three types of soil found in the department: brown tropical soils, highly unsaturated iron soils, and water-logged soils near rivers and marshes that are ideal for flooded cultivation of crops like rice (ICRAF 2011) (Fig. 1).

\section{Description of the selection criteria}

To facilitate the ranking of the tree species, selection criteria was designed using participatory approach to identify the most important variables and attributes for trees in cocoa farms (Table 1). The criteria include whether the tree grows naturally in Soubre, duration of maturity and inputs needs, enabling environment for tree growth such as availability of extension, germplasm and existence of marketing opportunities (both regional and international). We also considered the various uses which the tree can serve. Another important factor which was considered was whether the tree is a host to the CSSV or not. No matter the economic importance of the tree, it will not be encouraged to interplant with cocoa if it attracts or host the CSSV. The criteria and their explanations are provided in Table 1.

Sampling procedure and data collection

The first stage of data collection involved producer focus group meetings in 13 villages. In each village three separate focus groups were conducted in one day-one with women of mixed ages, one with men aged 18-40, and another with men over 40-with 10-15 participants in each meeting. In these focus groups, questions were asked about current and desired consumption of tree products, prices available for these products, inter-planting of trees with cocoa, and farmers' opinions about what alternative tree species would be most profitable for further development. The findings from these focus groups were supplemented with secondary source data from the literature, market and on farm observations and several interviews with key informants (five agroforestry researchers, three exporters and four extension agents). These data were then used to generate a list 


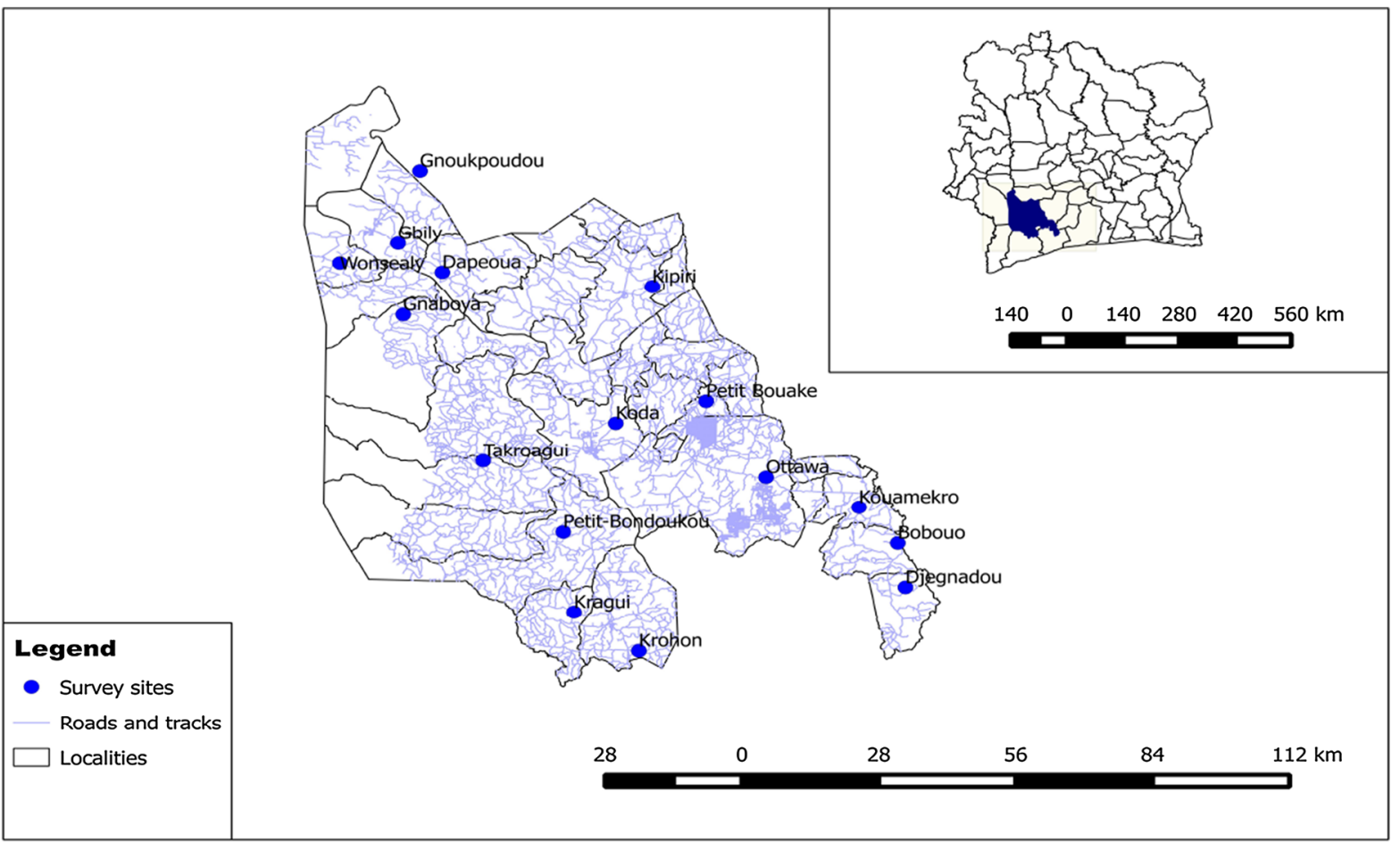

Fig. 1 Map of the study area

Table 1 Selection criteria for ranking of crops

\begin{tabular}{|c|c|c|}
\hline & Criterion & Explanation \\
\hline 1 & $\begin{array}{l}\text { Agro-ecological } \\
\text { suitability }\end{array}$ & $\begin{array}{l}\text { If it grows very well in } \\
\text { Soubré }\end{array}$ \\
\hline 2 & $\begin{array}{l}\text { Robustness, low cost of } \\
\text { cultivation }\end{array}$ & $\begin{array}{l}\text { Duration to maturity, inputs } \\
\text { needed, labor required }\end{array}$ \\
\hline 3 & Enabling environment & $\begin{array}{l}\text { Established extension, } \\
\text { germplasm supply, } \\
\text { marketing channels }\end{array}$ \\
\hline 4 & Current local abundance & $\begin{array}{l}\text { How common is the product } \\
\text { in the villages of Soubré }\end{array}$ \\
\hline 5 & $\begin{array}{l}\text { Potential to interplant } \\
\text { with cocoa }\end{array}$ & $\begin{array}{l}\text { Research results, farmer } \\
\text { willingness to plant }\end{array}$ \\
\hline 6 & Multiple uses & $\begin{array}{l}\text { Number of products yielded; } \\
\text { processing potential }\end{array}$ \\
\hline 7 & Local demand & $\begin{array}{l}\text { Local price; how widely is it } \\
\text { consumed, local market } \\
\text { risks }\end{array}$ \\
\hline 8 & $\begin{array}{l}\text { Regional and } \\
\text { international demand }\end{array}$ & $\begin{array}{l}\text { Price in larger towns, limits/ } \\
\text { risks to regional marketing, } \\
\text { export potential }\end{array}$ \\
\hline 9 & $\begin{array}{l}\text { Cocoa swollen shoot } \\
\text { virus(CSSV) protection }\end{array}$ & $\begin{array}{l}\text { Is it a good barrier crop to } \\
\text { prevent CSSV? }\end{array}$ \\
\hline
\end{tabular}

preferred tree species with economic potentials to be inter-planted with cocoa. Overall, 11 species came across as the most economically viable and important trees. Farmers were then asked to rank the 11 trees in order of importance based on several selection criteria, including local market demand, regional and export market demand, level of supportive institutions, multiple uses, potential for inter-planting with cocoa, current local abundance, and ease of cultivation in the region (Table 1). A score from 0 to $4(0=$ none, $1=$ very low, though $4=$ very high) was assigned to each crop for each criterion. The selection criteria was designed and the ranking done by a team of experts including farmers, researchers and extension agents. The top species from this list were then examined in more detail through a quantitative survey.

The second stage of data collection involved a random sample of 400 cocoa producer households surveyed in January and February 2013. The study area was divided into five approximately equal zones and a different surveyor was assigned to cover each zone. Within each zone ten villages were selected, and 
Table 2 List of villages in each zone

\begin{tabular}{ll}
\hline Zone & List of villages \\
\hline 1 & Gbily, Wonsealy (V2), Gnagboya (V4), Noukpoudou \\
& (LBS), Assamoikro, Irigopla, Dapeaoua, Petit- \\
& Yamoussoukro, Bohoussoukro, Petit Dioulabougou \\
2 & Kipiri, Petit-Bouaké, Krakro, Gnogboyo, Bakayo, \\
& Mayo, Koréguhé, Gbaléguhé, Godékro (yaokro), Sery \\
& Gbangan \\
& Koda (Doumbiadougou), Takoréagui, Pokouagui, \\
& Hana, Kouassi N'Guessankro, Adamagui, \\
& Kouakouagui, Petit Daloa, Yabayo, Gnanmangui \\
& Krohon, Kragui, Petit-Bondoukou, Touagui 2, \\
& Biagbanie (Miangabougo), Zangokro, Konanblekro, \\
& Bassa Koffikro, Touanié, Koffiagui \\
& Ottawa, Kouamékro, Bobouo 1, Tayo, Dioulabougou, \\
& Kpada, Guimeyo, Dobré, Bodouyo, Chantier
\end{tabular}

eight producer households were interviewed within each village. Villages were selected so as to have variety within the sample along several different variables: geographic location, level of isolation (distance from the nearest paved road), dominant ethnic group, and exposure to extension services. The list of villages selected for each zone is displayed in Table 2.

Surveyors were trained in sampling methods and survey implementation which included supervised test on-the-ground, before being sent to their separate zones. Few on farm visits were done randomly to triangulate information about the various trees farmers have in their fields. The information from on farm visit confirmed what farmers said during the interviews indicating that farmers had a fair idea about species and number of trees on their cocoa farms. The survey covered demographic data on farmers, geographic and market data on the village in which they lived, the number of each species of interest that was present on their land, data on the consumption and sale of products from these trees, and participation in producer associations and training programs. The household heads were interviewed.

\section{Model development}

To understand drivers of tree presence and densities, we adapted variables which have been used in past agroforestry adoption studies including household preferences (proxied by gender and education), resource endowments (total land, access to credit); market incentives (expected profits to be earned, distance to the market); biophysical factors (rainfall and soil quality); and risk and uncertainty (based on land tenure, migration status, and information access proxied by extension services and association membership) (Gyau et al. 2014; Pattanayak et al. 2003; Peterson et al. 1999; Adesina et al. 2000; Casey and Caviglia 2000; Neupane et al. 2002; Degrande et al. 2006; Pawarda et al. 2010). In line with other studies such as Besley and Case (1993), Conley and Udry (2001), Acemoglu et al. (2008) and Gamboa et al. (2010), social learning and networks was included in the model. We also included farmer attitudes toward a given technology and its importance in line with other studies such as Garforth et al. (2006), Prokopy et al. (2008) and Rezaei-Moghaddam and Salehi (2010).

Regression analysis was used to elicit the determinants of the presence and densities of the different targeted tree species. Factors influencing presence of trees in the cocoa farms were determined using a binomial logistic regression model also called the logit model. This is selected because the dependent variable (Presence of tree or not) is a binary variable (Sincich 1993). In general, when the number of independent variables is more than 1 , as in this study, the logistics equation is stated as below:

$f(z)=\frac{e^{z}}{e^{z}+1}=\frac{1}{1+e^{-z}}$

where $f(z)$ is the probability of whether a farmer has a given tree or not and is confined between 0 and 1 . The variable $\mathrm{z}$ is a measure of the total contribution of all the independent variables used in the model and is referred to as the logit. The variable $\mathrm{z}$ is usually defined as:

$z=\beta_{0}+\beta_{1} x_{1}+\beta_{2} x_{2}+\beta_{3} x_{3}+\ldots+\beta_{k} x_{k}$,

where $\beta_{0}$ is the intercept and $\beta_{1}, \beta_{2}, \beta_{3}, \ldots \beta_{\mathrm{k}}$ and so on, are the regression coefficients of $\mathrm{x}_{1}, \mathrm{x}_{2}, \mathrm{x}_{3} \ldots \mathrm{x}_{\mathrm{k}}$ respectively.

Specifically, the independent variables used to determine the presence of trees in cocoa farms include: farmers' origin, land size, availability of extension services, whether a farmer has bank account or not, Household size, distance to the nearest paved road, existence of non-agriculture revenue, labour, number 
Table 3 Socioeconomic characteristics of villages (mean value and percentages)

\begin{tabular}{lllllll}
\hline & Zone 1 & Zone 2 & Zone 3 & Zone 4 & Zone 5 & Pooled \\
\hline $\begin{array}{c}\text { Distance } \\
\text { to paved } \\
\text { road } \\
(\mathrm{km})\end{array}$ & 64.2 & 11.7 & 23.9 & 11.8 & 12 & 24.7 \\
$\begin{array}{c}\text { Quality } \\
\text { of road }\end{array}$ & 2.4 & 2.9 & 3.2 & 2.9 & 3 & 2.9 \\
$\begin{array}{c}\text { No. cocoa } \\
\text { buyers } \\
\text { based in } \\
\text { village }\end{array}$ & 4.9 & 4.3 & 5.7 & 1.9 & 3.6 & 4.1 \\
$\begin{array}{c}\% \text { With } \\
\text { market }\end{array}$ & 60 & 50 & 30 & 11.3 & 58.8 & 42 \\
$\begin{array}{c}\% \text { With } \\
\text { extension }\end{array}$ & 60 & 51.3 & 70 & 98 & 30 & 62 \\
\begin{tabular}{c} 
Population \\
\hline
\end{tabular} & 5,790 & 4,600 & 4,750 & 2,009 & 2,721 & 3,948 \\
\hline
\end{tabular}

of neighbours with trees, and price of the product. To test the determinants of tree density we use a linear OLS regression. In both cases all continuous variables are transformed into natural $\log$ form, such that each coefficient can be interpreted as the effect of $1 \%$ change in the independent variable on the dependent variable. Farmers' attitude towards agroforestry practices was added as additional independent variable to determine tree densities.

\section{Results}

Sample characteristics

Zone 1 is the farthest from the paved road $(64.2 \mathrm{~km})$ compared to zones 2 and 4 which are 11.7 and $11.8 \mathrm{~km}$ respectively (Table 3 ). The average distance to paved road is $24.7 \mathrm{~km}$ with the best road quality (measured by ranking from 0 to 5 ) found in zone 3 . Zone 1 has the highest number of population $(5,790)$ and zone 4 has the least $(2,009)$. In all, zone 4 has the least number of people who claimed to have market access for their products. Overall, $42 \%$ had access to markets. Sixtytwo percent of the population had access to extension information. Zone 5 lags behind the overall average with on $30 \%$ access. The average age of farmers in 5 zones is 50 years with a land size averaging 97.9 ha. People in zone 1 have the least number of land size (6.8 ha). Overall, migrants formed $83.5 \%$ of the total population divided into 51 and $32.5 \%$ respectively for internal and foreign migrants (Table 4).

Tree rankings

The top trees of economic value as ranked by farmers (Table 5) in order of importance are: oil palm (Elaeis guineensis) both industrial and wild, akpi (Ricinodendron heudelotii), timber species as a
Table 4 Demographic Characteristics of Producers (Mean values and percentages)

\begin{tabular}{lllllll}
\hline & Zone 1 & Zone 2 & Zone 3 & Zone 4 & Zone 5 & Pooled \\
\hline Age & 48.8 & 50.3 & 47.9 & 48 & 50 & 49 \\
Total land (ha) & 6.8 & 12.0 & 9.9 & 10.6 & 7.9 & 9.4 \\
Non-cocoa land (ha) & 0.8 & 3.0 & 2.0 & 1.5 & 2.3 & 1.9 \\
Household size & 12.6 & 11.6 & 13.8 & 12.7 & 10.8 & 12.3 \\
Cocoa yield (kg/ha) in 2012 & 419 & 277 & 249 & 402 & 425 & 353 \\
\% With non-agriculture revenue & 6.3 & 20 & 22.5 & 8.8 & 18.8 & 15.3 \\
\% With bank accounts & 13.8 & 25 & 28.8 & 33.8 & 17.5 & 23.8 \\
\% Land owners & 69 & 64 & 61 & 61 & 73 & 65.7 \\
\% No education & 52.5 & 42.5 & 67 & 73.8 & 71.3 & 61.4 \\
\% Native & 13.8 & 32.5 & 7.5 & 6.3 & 22.5 & 16.5 \\
\% Internal migrant & 57.5 & 52.5 & 56.5 & 55 & 33.8 & 51 \\
\% Foreign migrants & 28.7 & 11 & 36 & 38.7 & 43.7 & 32.5 \\
\% Coop members & 28.8 & 40 & 52.5 & 63.8 & 28.8 & 42.8 \\
\% Participating in extension & 27.5 & 42.5 & 51.3 & 73.8 & 18.8 & 42.8 \\
\% Replaced some cocoa & 2.5 & 5 & 7.5 & 10 & 3.8 & 5.8 \\
\% With CSSV & 58.8 & 63.8 & 18.8 & 13.8 & 5.1 & 32 \\
\hline
\end{tabular}


Table 5 Rankings of selected alternative tree species

\begin{tabular}{|c|c|c|c|c|c|c|c|c|c|c|c|c|}
\hline \multirow[t]{2}{*}{ Criterion } & \multicolumn{2}{|c|}{ Oil palm } & \multirow[t]{2}{*}{ Akpi } & \multirow{2}{*}{$\begin{array}{l}\text { Timber } \\
\text { species }\end{array}$} & \multirow[t]{2}{*}{ Orange } & \multirow[t]{2}{*}{ Rubber } & \multirow[t]{2}{*}{ Avocado } & \multirow[t]{2}{*}{ Mango } & \multirow{2}{*}{$\begin{array}{l}\text { Bush } \\
\text { mango }\end{array}$} & \multirow[t]{2}{*}{ Coconut } & \multirow[t]{2}{*}{ Kola } & \multirow[t]{2}{*}{ Papaya } \\
\hline & Wilc & Industrial & & & & & & & & & & \\
\hline $\begin{array}{l}\text { Agro-ecological } \\
\text { suitability }\end{array}$ & 3 & 3 & 4 & 3 & 4 & 3 & 3 & 4 & 4 & 3 & 4 & 3 \\
\hline $\begin{array}{l}\text { Ease of } \\
\text { cultivation }\end{array}$ & 4 & 2 & 4 & 2 & 4 & 2 & 4 & 2 & 3 & 2 & 3 & 2 \\
\hline $\begin{array}{l}\text { Enabling } \\
\text { environment }\end{array}$ & 2 & 4 & 1 & 1 & 2 & 4 & 1 & 2 & 0 & 1 & 3 & 1 \\
\hline $\begin{array}{l}\text { Current local } \\
\text { abundance }\end{array}$ & 4 & 3 & 1 & 2 & 2 & 3 & 2 & 2 & 1 & 1 & 1 & 1 \\
\hline $\begin{array}{l}\text { Interplanting } \\
\text { potential }\end{array}$ & 2 & 1 & 4 & 3 & 2 & 2 & 3 & 2 & 3 & 2 & 0 & 1 \\
\hline Multiple uses & 4 & 4 & 2 & 4 & 2 & 2 & 2 & 3 & 3 & 4 & 2 & 2 \\
\hline Local demand & 4 & 4 & 4 & 4 & 3 & 2 & 3 & 3 & 3 & 2 & 2 & 2 \\
\hline $\begin{array}{l}\text { Regional \& } \\
\text { export demand }\end{array}$ & 2 & 4 & 3 & 4 & 2 & 4 & 2 & 2 & 2 & 3 & 3 & 3 \\
\hline CSSV protection & 4 & 4 & 3 & 2 & 4 & 2 & 3 & 3 & 2 & 2 & 1 & 1 \\
\hline Total score & 29 & 29 & 26 & 25 & 25 & 24 & 23 & 23 & 21 & 20 & 19 & 16 \\
\hline Ranking & 1 & 1 & 2 & 3 & 3 & 4 & 5 & 5 & 6 & 7 & 8 & 9 \\
\hline
\end{tabular}

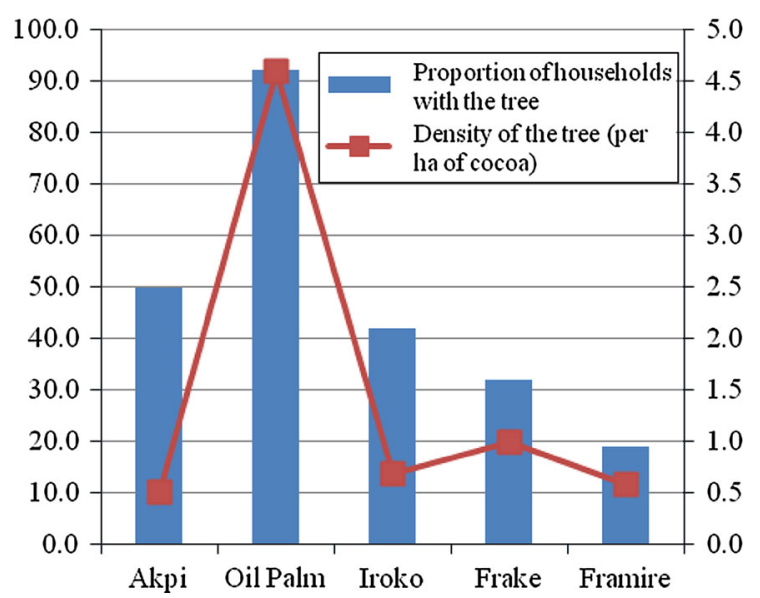

Fig. 2 Presence and densities of the selected tree species for the full sample

group, orange (Citrus sinensis), rubber (Hevea brasiliensis), avocado (Persea americana), mango (Mangifera indica), bush mango (Irvingia gabonensis), coconut (Cocos nucifera), kolanut (Cola nitida), and papaya (Carica papaya). Oil palm was divided into wild and industrial varieties for the purposes of analysis because these two types of palm have slightly different agronomic characteristics and serve separate markets.
Description of tree presence and densities

Proportion of households with specific trees as well as the densities measured by the average numbers of each tree per ha of cocoa is represented in Fig. 2. Big proportion of households has oil palm in their farms compared to other tree species. Furthermore, the densities of oil palm are also the highest. Although many farmers have akpi, the densities in their farms are the lowest. Timber species (Iroko, Frake and framire) have both low presence and densities.

Determinants of tree presence

The regression results for tree presence (Table 6) indicate that in all cases, the number of people in the village with the given tree has positive and a significant effect on tree presence. The calculated odds ratios indicate that a $10 \%$ increase in the number of villagers with the given tree would increase the odds of having akpi by almost 5 times, the odds of having palm by 16.8 times, the odds of having iroko by 4 times and the odds of having frake and framire by 3.8 times. Other variables differed dramatically depending on the tree species. In the case of akpi, natives were 2.5 times more likely to have the tree on their land compared to foreign migrants, and a $10 \%$ increase in total land size 
Table 6 Factors influencing tree presence in cocoa farms

\begin{tabular}{|c|c|c|c|c|c|c|}
\hline Variables & Akpi & Wild palm & Industrial palm & Iroko & Frake & Framire \\
\hline Origin 2-internal migrant & $\begin{array}{l}0.049 \\
-0.562\end{array}$ & $\begin{array}{l}2.179 \\
(0.52)^{* * * *}\end{array}$ & $\begin{array}{l}-2.4 \\
(0.695) * * *\end{array}$ & $\begin{array}{c}0.096 \\
(0.694)\end{array}$ & $\begin{array}{c}3.225 \\
(1.021)^{*}\end{array}$ & $\begin{array}{r}-0.240 \\
(0.898)\end{array}$ \\
\hline Origin 3-foreign migrant & $\begin{array}{l}-0.91 \\
(0.535)^{*}\end{array}$ & $\begin{array}{l}1.148 \\
(0.494)^{* *}\end{array}$ & $\begin{array}{l}-0.421 \\
-0.598\end{array}$ & $\begin{array}{r}-1.101 \\
(0.740)\end{array}$ & $\begin{array}{c}2.613 \\
(1.068)\end{array}$ & $\begin{array}{r}-1.612 \\
(3.039)\end{array}$ \\
\hline Zone 2 & $\begin{array}{l}-0.599 \\
-0.491\end{array}$ & $\begin{array}{l}1.173 \\
-0.78\end{array}$ & $\begin{array}{l}-3.868 \\
(2.116)^{*}\end{array}$ & $\begin{array}{c}-0.559 \\
(1.397)\end{array}$ & $\begin{array}{c}1.984 \\
(2.472)\end{array}$ & $\begin{array}{c}-1.088 \\
(3.263)\end{array}$ \\
\hline Zone 3 & $\begin{array}{l}0.188 \\
-0.544\end{array}$ & $\begin{array}{l}0.82 \\
-1.04\end{array}$ & $\begin{array}{l}0.579 \\
-1.49\end{array}$ & $\begin{array}{r}-0.364 \\
(1.284)\end{array}$ & $\begin{array}{r}-0.166 \\
(2.103)\end{array}$ & $\begin{array}{r}-0.680 \\
(1.178)\end{array}$ \\
\hline Zone 4 & $\begin{array}{l}0.44 \\
-0.632\end{array}$ & $\begin{array}{l}-1.59 \\
-1.09\end{array}$ & $\begin{array}{l}3.816 \\
(1.62)^{*}\end{array}$ & $\begin{array}{c}1.699 \\
(2.370)\end{array}$ & $\begin{array}{c}1.918 \\
(3.463)\end{array}$ & $\begin{array}{l}-7.398 \\
(10.507)\end{array}$ \\
\hline Zone 5 & $\begin{array}{l}0.019 \\
-0.646\end{array}$ & $\begin{array}{l}-0.401 \\
-0.76\end{array}$ & $\begin{array}{l}1.549 \\
-1.14\end{array}$ & $\begin{array}{c}0.408 \\
(1.546)\end{array}$ & $\begin{array}{c}3.398 \\
(2.198)\end{array}$ & $\begin{array}{r}-2.964 \\
(4.227)\end{array}$ \\
\hline Ln (total land size) & $\begin{array}{l}0.764 \\
(0.232) * * *\end{array}$ & $\begin{array}{l}0.002 \\
-0.31\end{array}$ & $\begin{array}{l}1.043 \\
(0.423)^{* *}\end{array}$ & $\begin{array}{c}0.755 \\
(0.403)^{*}\end{array}$ & $\begin{array}{l}2.322 \\
(0.635) * * *\end{array}$ & $\begin{array}{c}0.451 \\
(0.709)\end{array}$ \\
\hline Extension & $\begin{array}{l}0.568 \\
(0.333)^{*}\end{array}$ & $\begin{array}{l}0.196 \\
-0.529\end{array}$ & $\begin{array}{l}-0.974 \\
-0.603\end{array}$ & $\begin{array}{c}-0.101 \\
(0.541)\end{array}$ & $\begin{array}{c}-0.295 \\
(0.691)\end{array}$ & $\begin{array}{c}0.324 \\
(0.735)\end{array}$ \\
\hline Education & $\begin{array}{l}0.075 \\
-0.335\end{array}$ & $\begin{array}{l}-0.193 \\
-0.406\end{array}$ & $\begin{array}{l}-0.097 \\
-0.533\end{array}$ & $\begin{array}{r}-0.582 \\
(0.592)\end{array}$ & $\begin{array}{c}0.749 \\
(0.822)\end{array}$ & $\begin{array}{r}-0.850 \\
(0.814)\end{array}$ \\
\hline Coop member & $\begin{array}{l}-0.27 \\
-0.326\end{array}$ & $\begin{array}{l}0.29 \\
-0.412\end{array}$ & $\begin{array}{l}-0.317 \\
-0.633\end{array}$ & $\begin{array}{r}-0.345 \\
(0.520)\end{array}$ & $\begin{array}{l}2.305 \\
(0.861)^{* *}\end{array}$ & $\begin{array}{c}1.343 \\
(0.850)\end{array}$ \\
\hline Bank account & $\begin{array}{l}-0.202 \\
-0.354\end{array}$ & $\begin{array}{l}-0.938 \\
(0.391)^{* *}\end{array}$ & $\begin{array}{l}1.004 \\
(0.472)^{* *}\end{array}$ & $\begin{array}{r}-0.432 \\
(0.556)\end{array}$ & $\begin{array}{c}-0.457 \\
(0.774)\end{array}$ & $\begin{array}{c}0.246 \\
(0.777)\end{array}$ \\
\hline Ln (farmer age) & $\begin{array}{l}0.382 \\
-0.604\end{array}$ & $\begin{array}{l}0.609 \\
-0.73\end{array}$ & $\begin{array}{l}-0.344 \\
-0.887\end{array}$ & $\begin{array}{r}-1.153 \\
(1.061)\end{array}$ & $\begin{array}{c}-3.095 \\
(1.868)^{*}\end{array}$ & $\begin{array}{r}-0.526 \\
(1.817)\end{array}$ \\
\hline Ln (household size) & $\begin{array}{l}-0.234 \\
-0.312\end{array}$ & $\begin{array}{l}0.038 \\
-0.329\end{array}$ & $\begin{array}{l}0.333 \\
-0.316\end{array}$ & $\begin{array}{c}-0.391 \\
(0.476)\end{array}$ & $\begin{array}{c}0.960 \\
(0.681)\end{array}$ & $\begin{array}{r}-0.207 \\
(0.730)\end{array}$ \\
\hline Ln (distance to paved road) & $\begin{array}{l}-0.002 \\
-0.043\end{array}$ & $\begin{array}{l}0.171 \\
(0.053) * * *\end{array}$ & $\begin{array}{l}-0.337 \\
(0.122)^{* * *}\end{array}$ & $\begin{array}{c}0.055 \\
(0.075)\end{array}$ & $\begin{array}{c}0.150 \\
(0.126)\end{array}$ & $\begin{array}{r}-0.010 \\
(0.113)\end{array}$ \\
\hline Market & $\begin{array}{l}0.321 \\
-0.399\end{array}$ & $\begin{array}{l}-0.303 \\
-0.57\end{array}$ & $\begin{array}{l}1.026 \\
-0.813\end{array}$ & $\begin{array}{r}-0.038 \\
(0.914)\end{array}$ & $\begin{array}{r}-0.720 \\
(1.149)\end{array}$ & $\begin{array}{c}1.545 \\
(1.894)\end{array}$ \\
\hline Ln (village population) & $\begin{array}{l}-0.014 \\
-0.161\end{array}$ & $\begin{array}{l}0.107 \\
-0.14\end{array}$ & $\begin{array}{l}0.064 \\
-0.3\end{array}$ & $\begin{array}{c}0.537 \\
(0.431)\end{array}$ & $\begin{array}{c}0.171 \\
(0.868)\end{array}$ & $\begin{array}{c}0.531 \\
(1.139)\end{array}$ \\
\hline Non-agriculture revenue & $\begin{array}{l}-0.093 \\
-0.383\end{array}$ & $\begin{array}{l}-0.261 \\
-0.442\end{array}$ & $\begin{array}{l}-0.522 \\
-0.543\end{array}$ & $\begin{array}{l}1.365 \\
(0.579)^{* *}\end{array}$ & $\begin{array}{c}-0.302 \\
(0.869)\end{array}$ & $\begin{array}{c}0.263 \\
(0.721)\end{array}$ \\
\hline Ln (cocoa labor) & $\begin{array}{l}-0.069 \\
-0.28\end{array}$ & $\begin{array}{l}-0.107 \\
-0.139\end{array}$ & $\begin{array}{l}-2.32 \\
-0.269\end{array}$ & $\begin{array}{c}0.532 \\
(0.375)\end{array}$ & $\begin{array}{c}-0.921 \\
(0.498)^{*}\end{array}$ & $\begin{array}{r}-0.133 \\
(0.475)\end{array}$ \\
\hline Favorable AF attitude & $\begin{array}{l}-0.231 \\
-0.341\end{array}$ & $\begin{array}{l}0.484 \\
-0.428\end{array}$ & $\begin{array}{l}-0.996 \\
(0.519)^{*}\end{array}$ & $\begin{array}{r}-0.053 \\
(0.463)\end{array}$ & $\begin{array}{l}1.345 \\
(0.660)^{* *}\end{array}$ & $\begin{array}{r}-0.303 \\
(0.734)\end{array}$ \\
\hline Ln (no. villagers with tree) & $\begin{array}{l}1.605 \\
(0.360)^{* * *}\end{array}$ & $\begin{array}{l}-2.16 \\
-1.77\end{array}$ & $\begin{array}{l}7.05 \\
(1.87)^{* * *}\end{array}$ & $\begin{array}{c}1.351 \\
(0.716)\end{array}$ & $\begin{array}{c}1.295 \\
(0.899)\end{array}$ & $\begin{array}{l}0.823 \\
(0.384)^{* *}\end{array}$ \\
\hline Ln (village price product 1 ) & $\begin{array}{l}-0.279 \\
-0.548\end{array}$ & $\begin{array}{l}0.936 \\
-0.66\end{array}$ & $\begin{array}{l}-2.43 \\
(0.897)^{* * *}\end{array}$ & $\begin{array}{r}-0.229 \\
(1.972)\end{array}$ & $\begin{array}{r}-0.661 \\
(2.429)\end{array}$ & $\begin{array}{c}2.895 \\
(3.530)\end{array}$ \\
\hline Ln (village price product 2) & - & $\begin{array}{l}0.31 \\
-0.75\end{array}$ & $\begin{array}{l}-0.541 \\
-1.039\end{array}$ & $\begin{array}{r}-0.153 \\
(1.364)\end{array}$ & $\begin{array}{c}0.871 \\
(2.139)\end{array}$ & $\begin{array}{c}3.457 \\
(4.128)\end{array}$ \\
\hline
\end{tabular}


Table 6 continued

\begin{tabular}{llllccc}
\hline Variables & Akpi & Wild palm & Industrial palm & Iroko & Frake & Framire \\
\hline Ln (village price product 3) & - & -1.23 & -1.38 & 0.236 & -1.261 & -2.066 \\
& - & -1.08 & -1.78 & $(0.645)$ & $(1.114)$ & $(2.156)$ \\
Constant & -2.114 & 1.403 & 7.02 & -0.828 & 9.612 & -28.861 \\
& -4.083 & -7.74 & -10.66 & $(10.022)$ & $(19.207)$ & $(35.846)$ \\
Observations & 287 & 286 & 286 & 133.00 & 133.00 & 133.00 \\
Pseudo R-squared & 0.232 & 0.245 & 0.444 & 0.29 & 0.43 & 0.23 \\
\hline
\end{tabular}

Robust standard errors are shown in parenthesis

$*$ Indicates $90 \%$ significance; $* *=95 \%$; ** $=99 \%$

increased the odds of having akpi by 2.15 times. Extension also has a positive effect, increasing the odds of having akpi by 1.77 times. Regarding iroko, having $10 \%$ more total land and earning non-agricultural revenue increased the likelihood of having the tree slightly by 2.1 and 3.1 times, respectively.

A $10 \%$ increase in land area increase the odds of having frake by 10 times, as did being a cooperative member. Internal migrants were 25 times more likely to have frake than natives. Younger farmers and those with less labor to invest in cocoa tended to have more frake: a $10 \%$ increase in cocoa labor decreased the odds of having frake by 2.5 times, while a $10 \%$ increase in age decreased the odds by 22 times. Farmers with a favorable attitude toward agroforestry had 3.8 times higher odds of having frake. With regard to framire, only one variable was found to be significant: an increase in the number of people in the village with framire increased the odds by 2.3 times.

In the case of palm, the results were very different for the wild versus industrial varieties, and in a number of cases significant coefficients actually had opposite effects. Origin/ethnicity was found to be a significant factor, with internal migrants 8.8 times more likely to have wild palm and 11 times less likely to have industrial palm than native farmers. Foreign migrants were 3.2 times more likely to have wild palm than natives, though there was no significant different between the two groups for industrial palm. Wealth significantly increased presence of industrial palm but not wild palm; specifically, farmers with bank accounts were 2.6 times less likely to have wild palm but 2.7 times more likely to have industrial palm, and a $10 \%$ increase in land size increased the odds of having industrial palm by 2.8 .
Market access also had opposite effects on the two kinds of palm: a $10 \%$ increase in the distance from the paved road increased the odds of having wild palm by 1.2 but decreased the odds of having industrial palm by 1.4. A favorable attitude toward agroforestry decreased the odds of having an industrial palm plantation by 2.7 , but a $10 \%$ increase in the number of others in the village with industrial palm increased the odds by a factor of 11.5. Only one price factor was found significant, and also supported the notion that local (wild) and industrial palm markets move in opposite directions: a $10 \%$ increase in the local price for raw palm fruit lead to a decrease in the odds of having industrial palm by 11.4 .

\section{Determinants of tree densities}

Factors which influence tree densities (Table 7) have only one commonality in terms of significance and sign across more than a single type of tree. The number of people with a given tree in their farms has a significant, positive influence on tree density of akpi and frake. The coefficient shows that a $10 \%$ increase in the number of people in the village with the given tree increases the density of akpi by $65.8 \%$ and the density of frake by $22.7 \%$. In the case of akpi, being a foreign migrant instead of a native significantly decreased the density of akpi (by $173 \%$ ), while those living in zone 4 had $197 \%$ higher densities than those in zone 1. Having received cocoa extension services increased akpi density by $97 \%$, though it had no significant impact on the densities of other tree species. A $10 \%$ increase in farmer age led to a $130 \%$ increase in palm density, while internal migrants had densities $202 \%$ higher than natives. Densities of palm in cocoa farms in zone 5 were $182 \%$ 
Table 7 Determinants of tree density per ha of cocoa

\begin{tabular}{|c|c|c|c|c|c|}
\hline & Akpi & Palm & Iroko & Frake & Framire \\
\hline Origin 2-internal migrant & $\begin{array}{l}-0.146 \\
-0.7\end{array}$ & $\begin{array}{l}2.019 \\
(0.666)^{* * *}\end{array}$ & $\begin{array}{l}0.464 \\
(1.106)\end{array}$ & $\begin{array}{l}-0.839 \\
(1.721)^{*}\end{array}$ & $\begin{array}{l}-0.341 \\
(1.241)\end{array}$ \\
\hline Origin 3-foreign migrant & $\begin{array}{l}-1.731 \\
(0.748)^{* *}\end{array}$ & $\begin{array}{l}1.019 \\
-0.642\end{array}$ & $\begin{array}{l}-1.528 \\
(1.056)\end{array}$ & $\begin{array}{l}-0.097 \\
(1.782)\end{array}$ & $\begin{array}{l}-1.186 \\
(1.367)\end{array}$ \\
\hline Zone 2 & $\begin{array}{l}-0.285 \\
-0.825\end{array}$ & $\begin{array}{l}-0.948 \\
-0.683\end{array}$ & $\begin{array}{l}-0.063 \\
(2.037)\end{array}$ & $\begin{array}{l}1.768 \\
(1.043)\end{array}$ & $\begin{array}{l}0.866 \\
(0.974)\end{array}$ \\
\hline Zone 3 & $\begin{array}{l}0.922 \\
-0.799\end{array}$ & $\begin{array}{l}0.077 \\
-0.675\end{array}$ & $\begin{array}{l}0.298 \\
(1.937)\end{array}$ & $\begin{array}{l}-0.146 \\
(1.006)\end{array}$ & $\begin{array}{l}1.287 \\
(0.951)\end{array}$ \\
\hline Zone 4 & $\begin{array}{l}1.97 \\
(0.893)^{* *}\end{array}$ & $\begin{array}{l}-1.548 \\
-1.095\end{array}$ & $\begin{array}{l}5.339 \\
(4.115)\end{array}$ & $\begin{array}{l}3.439 \\
(3.852)\end{array}$ & $\begin{array}{l}-1.774 \\
(3.369)\end{array}$ \\
\hline Zone 5 & $\begin{array}{l}1.488 \\
-0.912\end{array}$ & $\begin{array}{l}-1.824 \\
(1.021)^{*}\end{array}$ & $\begin{array}{l}0.855 \\
(2.416)\end{array}$ & $\begin{array}{l}0.593 \\
(1.917)\end{array}$ & $\begin{array}{l}-0.514 \\
(1.663)\end{array}$ \\
\hline Ln (total land size) & $\begin{array}{l}0.381 \\
-0.318\end{array}$ & $\begin{array}{l}0.123 \\
-0.292\end{array}$ & $\begin{array}{l}0.849 \\
(0.545)\end{array}$ & $\begin{array}{l}0.843 \\
(0.533)\end{array}$ & $\begin{array}{l}-0.372 \\
(0.514)\end{array}$ \\
\hline Extension & $\begin{array}{l}0.969 \\
(0.492) * *\end{array}$ & $\begin{array}{l}-0.458 \\
-0.604\end{array}$ & $\begin{array}{l}-0.585 \\
(0.967)\end{array}$ & $\begin{array}{l}-0.347 \\
(0.905)\end{array}$ & $\begin{array}{l}0.366 \\
(0.715)\end{array}$ \\
\hline Education & $\begin{array}{l}0.292 \\
-0.507\end{array}$ & $\begin{array}{l}0.07 \\
-0.431\end{array}$ & $\begin{array}{l}-0.763 \\
(1.002)\end{array}$ & $\begin{array}{l}1.381 \\
(0.828)^{*}\end{array}$ & $\begin{array}{l}-0.700 \\
(0.671)\end{array}$ \\
\hline Coop member & $\begin{array}{l}-0.28 \\
-0.452\end{array}$ & $\begin{array}{l}0.199 \\
-0.414\end{array}$ & $\begin{array}{l}-0.741 \\
(0.786)\end{array}$ & $\begin{array}{l}1.144 \\
(0.737)\end{array}$ & $\begin{array}{l}0.635 \\
(0.758)\end{array}$ \\
\hline Bank account & $\begin{array}{l}-0.43 \\
-0.527\end{array}$ & $\begin{array}{l}-0.389 \\
-0.532\end{array}$ & $\begin{array}{l}-1.361 \\
(0.922)\end{array}$ & $\begin{array}{l}-1.122 \\
(0.915)\end{array}$ & $\begin{array}{l}-0.129 \\
(0.847)\end{array}$ \\
\hline Ln (farmer age) & $\begin{array}{l}0.673 \\
-0.964\end{array}$ & $\begin{array}{l}1.3 \\
(0.772)^{*}\end{array}$ & $\begin{array}{l}-1.165 \\
(1.845)\end{array}$ & $\begin{array}{l}-1.149 \\
(1.443)\end{array}$ & $\begin{array}{l}0.545 \\
(1.155)\end{array}$ \\
\hline Ln(household size) & $\begin{array}{l}-0.419 \\
-0.466\end{array}$ & $\begin{array}{l}-0.43 \\
-0.389\end{array}$ & $\begin{array}{l}-0.865 \\
(0.655)\end{array}$ & $\begin{array}{l}0.186 \\
(0.588)\end{array}$ & $\begin{array}{l}-0.478 \\
(0.502)\end{array}$ \\
\hline Ln (distance to paved road) & $\begin{array}{l}0.028 \\
-0.07\end{array}$ & $\begin{array}{l}0.008 \\
-0.079\end{array}$ & $\begin{array}{l}0.119 \\
(0.124)\end{array}$ & $\begin{array}{l}0.080 \\
(0.093)\end{array}$ & $\begin{array}{l}-0.012 \\
(0.111)\end{array}$ \\
\hline Market & $\begin{array}{l}0.467 \\
-0.592\end{array}$ & $\begin{array}{l}-0.43 \\
-0.53\end{array}$ & $\begin{array}{l}0.449 \\
(1.463)\end{array}$ & $\begin{array}{l}-0.136 \\
(1.223)\end{array}$ & $\begin{array}{l}0.670 \\
(1.001)\end{array}$ \\
\hline Ln (village population) & $\begin{array}{l}0.076 \\
-0.234\end{array}$ & $\begin{array}{l}-0.203 \\
-0.243\end{array}$ & $\begin{array}{l}0.768 \\
(0.705)\end{array}$ & $\begin{array}{l}-0.525 \\
(0.563)\end{array}$ & $\begin{array}{l}0.104 \\
(0.620)\end{array}$ \\
\hline Non-agriculture revenue & $\begin{array}{l}-0.464 \\
-0.581\end{array}$ & $\begin{array}{l}-0.049 \\
-0.602\end{array}$ & $\begin{array}{l}1.172 \\
(0.773)\end{array}$ & $\begin{array}{l}-0.273 \\
(0.822)\end{array}$ & $\begin{array}{l}0.253 \\
(0.694)\end{array}$ \\
\hline Ln (cocoa labor) & $\begin{array}{l}-0.025 \\
-0.264\end{array}$ & $\begin{array}{l}0.036 \\
-0.133\end{array}$ & $\begin{array}{l}0.321 \\
(0.193)^{*}\end{array}$ & $\begin{array}{l}-0.182 \\
(0.151)\end{array}$ & $\begin{array}{l}0.017 \\
(0.125)\end{array}$ \\
\hline $\begin{array}{l}\text { Favorable attitude towards } \\
\text { agroforestry }\end{array}$ & $\begin{array}{l}-0.26 \\
-0.453\end{array}$ & $\begin{array}{l}0.506 \\
-0.461\end{array}$ & $\begin{array}{l}-0.114 \\
(0.763)\end{array}$ & $\begin{array}{l}1.440 \\
(0.755)^{*}\end{array}$ & $\begin{array}{l}-0.315 \\
(0.635)\end{array}$ \\
\hline Ln (no. villagers with tree) & $\begin{array}{l}0.658 \\
(0.091)^{* * *}\end{array}$ & $\begin{array}{l}-0.27 \\
-0.58\end{array}$ & $\begin{array}{l}1.483 \\
(1.107)\end{array}$ & $\begin{array}{l}0.227 \\
(0.088) * *\end{array}$ & $\begin{array}{l}0.095 \\
(0.108)\end{array}$ \\
\hline Ln (village price product 1 ) & $\begin{array}{l}-0.223 \\
-0.771\end{array}$ & $\begin{array}{l}-0.081 \\
-0.468\end{array}$ & $\begin{array}{l}0.551 \\
(2.863)\end{array}$ & $\begin{array}{l}-1.645 \\
(2.585)\end{array}$ & $\begin{array}{l}2.459 \\
(2.431)\end{array}$ \\
\hline Ln (village price product 2 ) & - & $\begin{array}{l}-0.547 \\
-0.887\end{array}$ & $\begin{array}{l}-1.652 \\
(2.094)\end{array}$ & $\begin{array}{l}-1.784 \\
(1.821)\end{array}$ & $\begin{array}{l}0.103 \\
(1.578)\end{array}$ \\
\hline
\end{tabular}


Table 7 continued

\begin{tabular}{lllllll} 
Table 7 continued & & Akpi & Palm & Iroko & Frake & Framire \\
\cline { 2 - 6 } & Ln (village price product 3) & - & 0.181 & 0.610 & 1.073 & -1.153 \\
& & - & -0.712 & $(1.088)$ & $(1.031)$ & $(1.014)$ \\
Robust standard errors are & Constant & -7.431 & 0.656 & -1.048 & 12.283 & -13.999 \\
shown in parenthesis & & -6.05 & -8.343 & $(16.882)$ & $(14.439)$ & $(12.321)$ \\
$*$ Indicates $90 \%$ & Observations & 281 & 242 & 129 & 129 & 129 \\
significance; $* *=95 \% ;$ & R-squared & 0.22 & 0.18 & 0.22 & 0.28 \\
$* * *=99 \%$ & & & & & & 0.14 \\
\hline
\end{tabular}

lower than those in zone 1 . The density of iroko in cocoa farms was found to increase by $32.1 \%$ with a $10 \%$ increase in cocoa labor, but no other variables had a significant effect. In the case of frake, being educated increased the density of the tree by $138 \%$, having a favorable attitude toward agroforestry increased it by $144 \%$, and a $10 \%$ increase in the number of other villagers with the tree increased the density by $22.7 \%$. Internal migrants had $83.9 \%$ lower densities of akpi than native populations. None of the factors in the regression were found to have a significant impact on framire density.

\section{Discussions}

The results indicate that the presence and density of the different trees are affected by different variables, although there are a few commonalities. Specifically, the number of farmers in a village who have the given tree influences presence of akpi, industrial palm, and framire, as well as density of akpi and frake positively. This indicate that both social contagion/neighbourhood effects and positive attitudes toward a given technology will increase adoption (Besley and Case 1993; Conley and Udry 2001; Garforth et al. 2006; Acemoglu et al. 2008; Prokopy et al. 2008; Gamboa et al. 2010; Rezaei-Moghaddam and Salehi 2010). Farmer origin was included in our model as a proxy for land ownership, because native populations have the most secure land tenure and usually rent or sell the land to the migrant populations. Even though many migrant families have worked the same land for generations, they have slightly less secure tenure, especially in some regions, where natives have tried to reclaim the land ceded to the migrants in the past. This mainly results from the fact that although under the laws of Côte d'Ivoire the land belonged to the state, the government had always in practice accepted customary law, which held that land belonged to the lineage of the people who first settled and cultivated it (USAID 2013). This situation contradicts the previous policy which existed from the 1960s to the early 1990 s when land was said to belong to people who develop it. Consequently, there are reports of conflicts resulting from attempts by unemployed urban youth who returned to their home villages to seek their livelihood and found that most of the productive land was in the hands of migrant farmers (USAID 2013).

In the case of akpi foreign migrants have significantly lower tree densities which are attributed to consumption preferences. In Côte d'Ivoire it was observed that greater percentage of natives consume more akpi compared to both internal and foreign migrants and hence the tendency to leave akpi trees on their farms. Furthermore, both foreign and internal migrants are significantly more likely to have wild palm than natives. Internal migrants had a higher likelihood of having frake on their land than natives, as well as higher densities of wild palm. This is surprising as palm is consumed by all in Côte d'Ivoire.

Land size constitutes another significant commonality, in that it has a positive effect on the presence of akpi, industrial palm, iroko and frake. This is consistent with past results such as Peterson et al. (1999) and Phiri et al. (2004)which found a clear positive impact of land area and wealth on agroforestry adoption. Farmers with more land are wealthier and thus, less risk averse, so they might be more willing and able to plant trees compared to those with small land sizes (Casey and Caviglia 2000; Degrande et al. 2006).

Having a bank account was only significant for the presence of the two palm varieties, increasing the likelihood of having industrial palm but decreasing the likelihood of having wild palm. This finding is in line with Degrande et al. (2006), who suggest that poorer households retain wilder palm for home consumption, while the wealthier farmers are those who tend to 
invest in industrial palm. Non-agricultural revenue positively influenced both the presence of iroko but had no other significant effects, which is also consistent with the argument that wealthier farmers will plant more trees on farm.

Education was only found to be significant in one case, increasing the density of frake, which is consistent with past findings. Though education is often included as a variable in adoption models, it is very often not significant (Pattanayak et al. 2003; Gyau et al. 2012). Cooperative membership was also not significant in most of our models, except that it increased framire density. This is somewhat in contrast to many studies which have found a highly significant impact of group membership on adoption (Adesina et al. 2000; Casey and Caviglia 2000; Neupane et al. 2002). Surprisingly, there is no significant relationship between extension services on tree presence and densities in all cases except akpi, which is in contrast with many past studies which observed high significance levels and positive impacts of extension (Adesina et al. 2000; Casey and Caviglia 2000). This may indicate that certification bodies and other extension efforts, though are certainly promoting general tree planting and management in cocoa farms, have not done much to promote the selected tree species.

\section{Conclusion and recommendations}

From above it can be recommended that organizations interested in promoting cocoa agroforestry could thus begin by focusing on larger land holders, just too quickly increase the total number of shade trees in the system. Secondly, the general results on the variables which proxy for farmers' wealth suggest that poorer farmers are more willing to consider planting trees such as oil palm in their cocoa farms, a species that yields products for household consumption. These results indicate that organizations promoting agroforestry among poorer smallholders will have more success if they promote tree species which are in high demand among the local population for their own consumption, regardless of market prices.

Furthermore, farmers who have a positive attitude toward planting trees in cocoa farms, either due to information received from their cooperative, extension agents, or other farmers, were also more likely to act on these attitudes and plant more trees. This indicates support for the value of extension efforts to spread awareness of how trees on farm can positively impact cocoa sustainability and livelihoods. Finally, positive effects of social networks on tree planting in cocoa farms suggests that extension organizations can use this trend to their advantage by focusing on promotion of tree planting to a certain core population, and then allowing additional farmers to learn from and be influenced by the early adopters. This could potentially save time and money by reducing the number of trainings.

Open Access This article is distributed under the terms of the Creative Commons Attribution License which permits any use, distribution, and reproduction in any medium, provided the original author(s) and the source are credited.

\section{References}

Acemoglu D, Dahleh M, Lobel I, and Ozdaglar A (2008) "Bayesian learning in social networks." National Bureau of Economic Research: Cambridge, Working Paper 14040

Adesina AA, Mbila D, Nkamleu GB, Endamana D (2000) Econometric analysis of the determinants of adoption of alley farming by farmers in the forest zone of southwest Cameroon. Agric Ecosyst Environ 80(3):255-265

Adou Yao CY, N'Guessan KE (2006) Diversité floristique spontanée des plantations de café et de cacao dans la forêt classée de Monogaga, Côte d'Ivoire. Schweiz Z Forstwes 157(2):31-36

Aké-Assi L (2001) Flore de la Côte d'Ivoire 1, catalogue, systématique, biogéographie et écologie. Boisseria 57:396

Aké-Assi L (2002) Flore de la Côte d'Ivoire 2, catalogue, systématique, biogéographie et écologie. Boisseria 58:441

Akrofi A, Appiah A, Opoku I (2003) Management of Phytophthora pod rot disease on cocoa farms in Ghana. Crop Prot 22(3):469-477

Asare R (2005) Cocoa agroforests in West Africa: a look at activities on preferred trees in the farming systems." Forest \& Landscape Working Papers no. 6-2005

Assiri AA, Kacou ZA, Assi FA, Ekra KS, Kacou EA, Dji KF, Couloud JY, Yapo AR (2012) Rentabilité économique des techniques de réhabilitation et de replantation des vieux vergers de cacaoyers (Theobroma cacao L.) en Côte d'Ivoire. J Anim Plant Sci 14(2):1939-1951

Besley T, Case A (1993) Modelling technology adoption in developing countries. Am Econ Rev 83(2):396-402

Casey JF and Caviglia JL (2000) Deforestation and agroforestry adoption in tropical forests: can we generalize? some results from Campeche, Mexico and Rondônia, Brazil. In: Western agricultural economics association annual meetings, Vancouver, British Columbia

Cloug Y, Faust H, Tscharntk T (2009) Cacao boom and bust: sustainability of agroforests and opportunities for biodiversity conservation. Conserv Lett 2:197-205

Conley T, Udry C (2001) Social learning through networks: the adoption of new agricultural technologies in Ghana. Am J Agric Econ 83(3):668-673 
Degrande A, Schreckenberg K, Mbosso C, Anegbeh P, Okafor V, Kanmegne J (2006) Farmers' fruit tree-growing strategies in the humid forest zone of Cameroon and Nigeria. Agrofor Syst 67(2):159-175

Dumont ES, Gnahoua GM, Ohouo L, Sinclair FL, Vaast P (2014) Farmers in Côte d'Ivoire value integrating tree diversity in cocoa for the provision of ecosystem services. Agrofor Syst. doi:10.1007/s10457-014-9679-4

Fair Labor Association (FLA) (2012) Sustainable management of Nestlé's cocoa supply chain in the Ivory Coast-focus on labor standards. Fair Labor Association, Washington, D.C.

Gamboa VG, Barkmann J, Marggraf R (2010) Social network effects on the adoption of agroforestry species: preliminary results of a study on differences on adoption patterns in Southern Ecuador. Procedia-Soc Behav Sci 4:71-82

Garforth Chris, McKemey Kevin, Rehman Tahir, Tranter Richard, Cooke Richard, Park Julian, Dorward Peter, Yates Chris (2006) Farmers' attitudes towards techniques for improving oestrus detection in dairy herds in South West England. Livest Sci 103:158-168

Gibson J (2007) Consistently inconsistent: addressing income volatility among cocoa producers in Ghana and Côte d'Ivoire. International Institute for Sustainable Development, Winnipeg

Gockowski, J. and Dury, S. (1999) The economics of cocoa-fruit agroforests in southern Cameroon. Paper present to International Workshop on Multi-strata Systems with Perennial Tree Crops. CATIE, Costa Rica, 22-25 February 1999

Gyau A, Chiatoh M, Franzel S, Asaah E, Donovan J (2012) Determinants of farmers' tree planting behaviour in the North West region of Cameroon: the case of Prunus africana. Int For Rev 14(3):265-274

Gyau A, Smoot K, Kouame C, Diby L, Ofori D (2014) Farmer attitudes towards trees in cocoa farms in Cote d'Ivoire. Agrofor Syst. doi:10.1007/s10457-014-9677-6

ICRAF (2011) Presentation synoptique du department de Soubré. World Agroforestry Center Vision for Change Project, Internal Document

International Institute of Tropical Agriculture (IITA) (2009) The productivity of cocoa systems in West Africa. Presentation at the 7th regional executive committee meeting of the sustainable tree crop programme. Accra, Ghana 25-28 Oct 2009

Kouadio KKH, Doudou DT, Tschannen A, Dao D, Girardin O (2011) Techniques agroforestières à base de Gliricidia sepium à l'Est de la Côte d'Ivoire : impacts et perspectives. J Anim Plant Sci 11(1):1374-1379

Kouadjo J, Kého Y, Mosso RA, Toutou KG (2002) Production et offre du cacao et du café en Côte d'Ivoire. Survey Report, ENSEA-Sustainable Tree Crops Program, International Institute of Tropical Agriculture

Matissek R, Reinecke O, Manning S (2012) Sustainability in the cocoa sector: review, challenges and approaches. LCI Moderne Ernährung Heute 1

Neupane RP, Sharma KR, Thapa GB (2002) Adoption of agroforestry in the hills of Nepal: a logistic regression analysis. Agric Syst 72(3):177-196
Obiri D, Geoff B, Morag A, Luke C, Cobbina J (2007) Financial analysis of shaded cocoa in Ghana. Agrofor Syst 71:139-149

Ofori-Frimpong K, Asase A, Mason J, Danku L (2007) Shaded versus unshaded cocoa: implications on litter fall, decomposition, soil fertility and cocoa pod development. Presented at the symposium on multistrata agroforestry systems with perennial crops, CATIE Turrialba, Costa Rica, 17-21 Sept 2007

Pattanayak SK, Mercer DE, Sills E, Yang JC (2003) Taking stock of agroforestry adoption studies. Agrofor Syst 57(3):173-186

Pawarda C, Gadzirayi CT, Muriritirwa WT, Mwenye D (2010) Adoption of agroforestry technologies among smallholder farmers: a case of Zimbabwe. J Dev Agric Econ 2(10):351-358

Peterson JS, Tembo L, Kawimbe C, Mwangamba E (1999) The Zambia integrated agroforestry project baseline survey: lessons learned in Chadiza, Chipata, Kateteand Mambwe districts, Eastern Province, Zambia. World Vision, University of Florida and Ministry of Agriculture

Phiri D, Franzel S, Mafongoya PL, Jere I, Katanga R, Phiri S (2004) Who is using the new technology? The association of wealth status and gender with the planting of improved tree fallows in Eastern Province, Zambia. Agric Syst 79(2):131-144

Prokopy LS, Floress K, Klotthor-Weinkauf D, Baumgart-Getz A (2008) Determinants of agricultural best management practice adoption: evidence from the literature. J Soil Water Conserv 63(5):300-311

Rezaei-Moghaddam Kurosh, Salehi Saeid (2010) Agricultural specialists' intention toward precision agriculture technologies: integrating innovation characteristics to technology acceptance model. Afr J Agric Res 5(11):11911199

Ruf F (2001) Tree Crops as Deforestation and Reforestation Agents: the Case of Cocoa in Côte d'Ivoire and Sulawesi. In: Anglesen A, Kaimowitz D (eds) Agricultural technologies and tropical deforestation. CABI Publishing, Oxon

Sincich T (1993) Statistics by example, 5th edn. MacMillan, New York

Smoot K, Gyau A, Kouame C, Diby L (2013) Market analysis of selected agroforestry products in the vision for change project intervention zone, Côte d'Ivoire. ICRAF Working paper 174, Nairobi, Kenya. http://dx.doi.org/10.5716/ WP13249.PDF

Somarriba E, Beer J (2011) Productivity of Theobroma cacao agroforestry systems with timber or legume service shade trees. Agrofor Syst 81:109-121

Tropical Commodity Coalition (TCC) (2010) Cocoa barometer 2010

USAID 2013. Property rights and resource governance, Côte d'Ivoire: USAID country profile. www.usaidlandtenure. net/.../USAID_Land_Tenure_Cote_d'Ivoire_Profile.pdf. Accessed 16 May 2014 